\title{
Endopolygalacturonase Genes from Colletotrichum lindemuthianum: Cloning of CLPG2 and Comparison of Its Expression to That of CLPG1 During Saprophytic and Parasitic Growth of the Fungus
}

\author{
Sylvie Centis, Isabelle Guillas, Nathalie Séjalon, Marie-Thérèse Esquerré-Tugayé, \\ and Bernard Dumas \\ UMR 5546 CNRS-UPS, Signaux et Messages Cellulaires chez les Végétaux, Centre de Biologie et Physi- \\ ologie Végétales, Université Paul Sabatier, 118 route de Narbonne, 31062 Toulouse Cedex, France \\ Received 13 February 1997. Accepted 29 May 1997.
}

Following the previous isolation of CLPG1, a gene encoding an endopolygalacturonase (endoPG) secreted into the culture filtrate of Colletotrichum lindemuthianum, we have isolated and sequenced an additional endoPG gene, CLPG2. This gene is present as a single copy in the genome of the fungus. At the amino acid level, CLPG2 shows 61\% identity to CLPG1 and between 37 to $59 \%$ identity to other fungal endoPGs. RNA blot analyses of endoPG gene expression were followed with specific probes during in vitro culture of the fungus. When conidia were used to inoculate a synthetic medium containing pectin as sole carbon source, only CLPG1 was found to be expressed after 3 days of culture. However, transferring the mycelium grown on glucose for $\mathbf{4}$ days to a pectin-containing medium allowed the detection of CLPG1 and CLPG2 transcripts as early as $12 \mathrm{~h}$ after transfer on this substrate. Expression of CLPG2 was transient while that of CLPG1 was more prolonged. Immunocytological localization of endoPG in $C$. lindemuthianum-infected bean tissues with antibodies against CLPG1 confirmed that the protein is produced in planta and is associated with extensive degradation of the host cell wall. Detection of endoPG transcripts by reverse transcription-polymerase chain reaction revealed that $C L P G 1$, but not $C L P G 2$, is expressed at the beginning of the necrotrophic stage of infection. These results show that the two endoPG genes are differentially expressed and that $C L P G 1$ encodes the major secreted endoPG both during saprophytic growth and during plant infection.

Additional keywords: Phaseolus vulgaris.

The very first contact of microbial plant parasites with their hosts occurs at the cell surface. During penetration and colonization, fungal pathogens secrete plant cell walldegrading enzymes that are thought to be primarily involved

Corresponding author: Bernard Dumas; Phone: (33) (0) 561-55-67-58; Fax: (33) (0) 561-55-83-78; E-mail: dumas@ cict.fr

Nucleotide sequence data are to be found at the EMBL Nucleotide Sequence Database as accession number X95457. in the necrotrophic stage of pathogenesis (Walton 1994). In a number of systems, strong correlations have been established between the presence of pectinolytic enzymes, disease symptoms, and virulence (Durrands and Cooper 1988). While pectic enzymes have been purified and characterized from several fungal parasites (for review see Alghisi and Favaron 1995), there are relatively few molecular studies investigating their role during pathogenesis. Genes encoding endopolygalacturonases (endoPGs) have been isolated from a number of pathogenic fungi, notably Cochliobolus carbonum (Scott-Craig et al. 1990), Fusarium moniliforme (Caprari et al. 1993), Sclerotinia sclerotorium (Reymond et al. 1994), Colletotrichum lindemuthianum (Centis et al. 1996), and Cryphonectria parasitica (Gao et al. 1996). An endoPG mutant of Cochliobolus carbonum generated by gene disruption did not show a reduction in pathogenicity (Scott-Craig et al. 1990), suggesting that this endoPG does not play a role during maize infection. However, results of gene disruptions should be interpreted carefully when drawing definite conclusions about the role of a particular enzymic activity in pathogenesis, since it has been shown that genes not expressed during saprophytic growth can be specifically induced during infection (Yao and Köller 1995; Gao et al. 1996). Thus, it is essential to check whether all the genes encoding for a given enzyme have been identified. To reach this goal, we have undertaken the cloning and characterization of the endoPG genes of Colletotrichum lindemuthianum, a hemibiotroph fungal pathogen that causes anthracnose on bean seedlings (Bailey et al. 1992).

When grown on a pectin-containing liquid medium, this fungus secretes a single endoPG that has been thoroughly characterized with molecular probes (Hugouvieux et al. 1995). EndoPG activity is partly inhibited during the parasitic stage of the fungus by the bean cell wall polygalacturonase inhibitory protein (PGIP), (Albersheim and Anderson 1971; Lafitte et al. 1984; Wijesundera et al. 1989). The strong and specific affinity of PGIP for endoPG was exploited when gold-labeled PGIP was used as a probe to detect endoPG and associated cell wall degradation in planta during infection of bean tissues (Benhamou et al. 1991). We recently reported that the endoPG purified from $C$. lindemuthianum race $\beta$ elicits the biosynthe- 
sis of pathogenesis-related (PR) proteins in bean cuttings, notably $\beta$-1,3-glucanase, in a cultivar-specific manner (Lafitte et al. 1993), suggesting an important role for this fungal protein in triggering the expression of host defense genes. A geneencoding endoPG, CLPG1, was cloned and characterized previously (Centis et al. 1996). Since the protein sequence deduced from this gene contains the $\mathrm{N}$ terminus sequence of the enzyme isoform secreted by $C$. lindemuthianum grown in vitro, it was suggested that CLPG1 corresponds to the gene expressed during saprophytic growth of the fungus (Centis et al. 1996). However, Southern blot analyses revealed that an additional endoPG gene was present in the genome (Centis et al. 1996). In this paper, we report on the cloning and sequencing of this gene, CLPG2, and show that it encodes a protein with significant homology to other fungal endoPGs. The expression pattern of the two endoPG genes during in vitro culture of the fungus and during the necrotrophic stage of pathogenesis is also presented.

\section{RESULTS}

\section{Isolation and characterization of $C L P G 2$.}

A subgenomic library of $C$. lindemuthianum race $\beta$ constructed in the vector $\lambda$ ZapII (Centis et al. 1996) was probed with a 542-bp polymerase chain reaction (PCR) fragment, named $p g A$, corresponding to nucleotides 300 to 842 of the CLPG1 gene (Centis et al. 1996). One positive clone showing a weak hybridization signal was purified and submitted to in vivo excision. Nucleotide sequencing was done on 2,020 nucleotides according to standard procedures (Sanger et al. 1977). As shown on Figure 1, this sequence contains an open reading frame of $1,098 \mathrm{bp}$ interrupted by one putative intron of $53 \mathrm{bp}$ (Fig. 1). Alignment of the amino acid sequence deduced from this open reading frame with CLPG1 revealed $61 \%$ identity amino acid identity (Fig. 2). The N-terminal portion of the deduced protein is rich in hydrophobic amino acid residues, suggesting the presence of a signal peptide. Indeed, residues 25 to 61 show a high level of identity with the $\mathrm{N}$ terminus amino acid sequence of the purified CLPG1 protein (Fig. 2) (Keon et al. 1990). Comparison of the CLPG2 amino acid sequence to that of other fungal endoPGs revealed amino acid identities ranging from 37 to $59 \%$ (Fig. 2). The calculated molecular mass and isoelectric point of CLPG2, $37.9 \mathrm{kDa}$ and 9.9, respectively, are closely related to the values calculated for CLPG1, $36.7 \mathrm{kDa}$ and 8.3, respectively (Centis et al. 1996). A potential $N$-glycosylation site (AsnGly-Ser) consistent with the glycoproteic nature of endoPG (Keon et al. 1990) is found at Asn 294. From these analyses, it appears that the newly isolated gene closely resembles $C L P G 1$, a previously reported endoPG gene. Accordingly, it was termed $C L P G 2$.

Southern blot analysis of $C$. lindemuthianum race $\beta$ genomic DNA digested with $X b a \mathrm{I}$ or $X h o I$ revealed that two major fragments hybridized with $p g A$ (Fig. 3A). We showed previously that the upper XhoI fragment contains CLPGI (Centis et al. 1996). To check whether the other fragment corresponded to $C L P G 2$, a specific probe corresponding to the $5^{\prime}$ noncoding end of the gene was prepared. Fig. 3B shows that this probe hybridized with one of the $X b a \mathrm{I}$ and $X h o \mathrm{I}$ fragments, suggesting that $C L P G 2$ is present as a single-copy gene in the haploid genome of the fungus.

\section{Expression of endoPG genes in C. lindemuthianum grown in vitro.}

Through the use of a heterologous endoPG probe, it was previously shown that pectin induces endoPG gene expression in $C$. lindemuthianum race $\beta$ (Hugouvieux et al. 1995). To determine the individual contribution of each endoPG gene in this response, specific probes for CLPG1 and CLPG2 were prepared for RNA blot experiments. The $C L P G 1$ probe corresponded to a 800-bp fragment covering the $3^{\prime}$ end of the coding sequence and nontranslated region while the $C L P G 2$ probe consisted of a 2-kb fragment encompassing the coding sequence and covering the $5^{\prime}$ and $3^{\prime}$ nontranslated regions. The specificity of the probes was checked by Southern blotting of the DNA corresponding to CLPG1 (Centis et al. 1996) and CLPG2 coding sequences excised from the cloning vector pBluescript. As shown in Figure 4, no cross-hybridization was detected when up to $1 \mathrm{ng}$ of CLPG1 or CLPG2 was loaded onto the gel, thus allowing expression of the two genes to be specifically assessed with the two probes. EndoPG gene expression was first studied in mycelium obtained from a me-

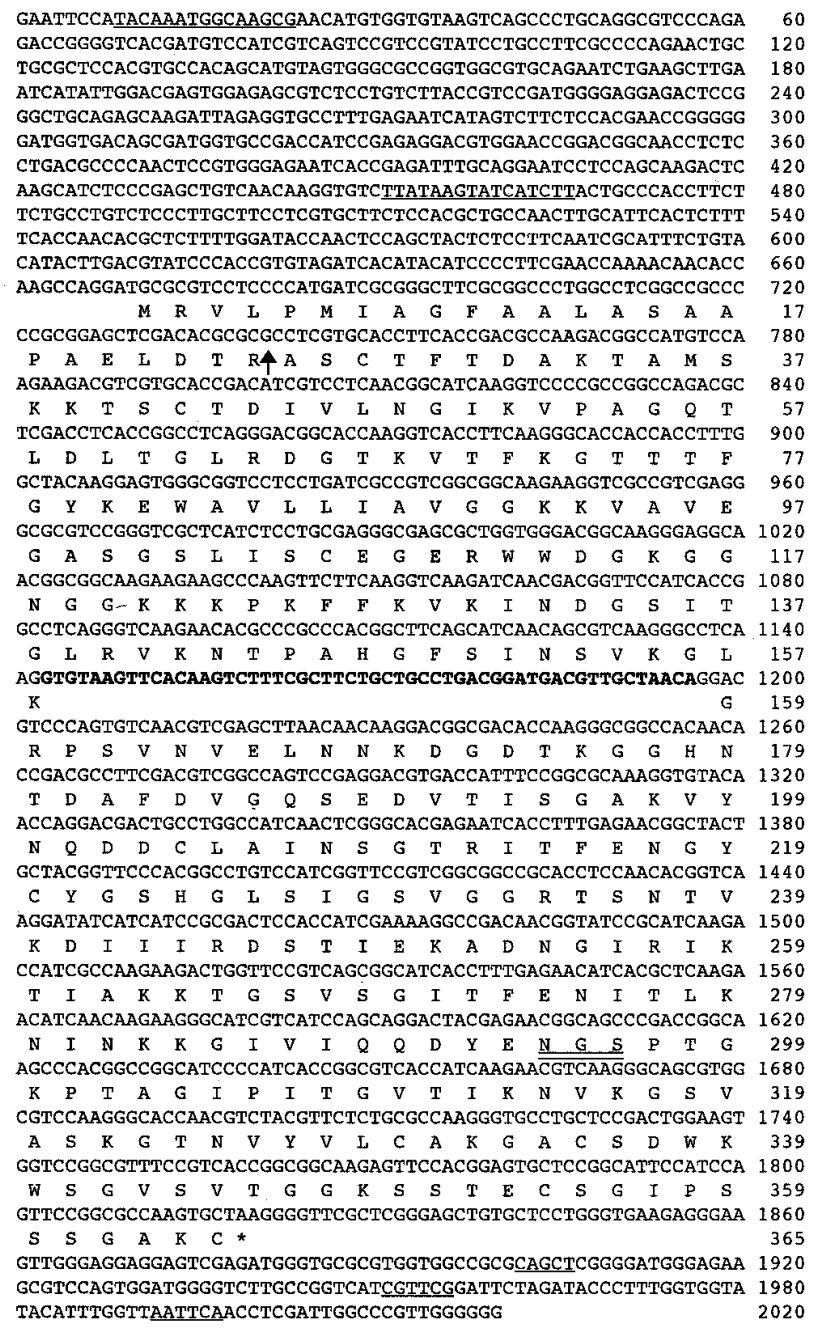

Fig. 1. Nucleotide sequence of the CLPG2 gene and deduced amino acid sequence. Putative TATA box and sites of polyadenylation are underlined. Stop codon is marked by an asterisk. A putative glycosylation site is double underlined. The single intron is indicated in bold type. 
dium containing pectin as sole carbon source or a mixture of pectin and glucose inoculated with a suspension of conidia. Northern (RNA) blot analysis of total RNA extracted 3 and 5 days postinoculation showed that only CLPG1 was induced in a 3-day-old culture of the fungus on pectin (Fig. 4). Induction of $C L P G 1$ was transient, partly repressed by glucose, and decreased at day 5 on either medium. Such kinetics are consistent with the previously reported transient induction of endoPG activity by pectin (Hugouvieux et al. 1995). In the same conditions of culture, expression of CLPG2 was not detected.

To thoroughly investigate the effect of pectin at early stages of growth, the fungus was precultivated on glucose for 4 days to allow biomass to accumulate before being transferred to pectin. In this case, induction of both endoPG genes occurred after $12 \mathrm{~h}$ of growth on pectin (Fig. 4). The two transcripts exhibited the same size $(1.6 \mathrm{~kb})$ and nearly the same intensity. Expression of the two genes was transient, being still visible for $C L P G 1$ at $18 \mathrm{~h}$ while no longer detectable for $C L P G 2$ at the same time (Fig. 4).

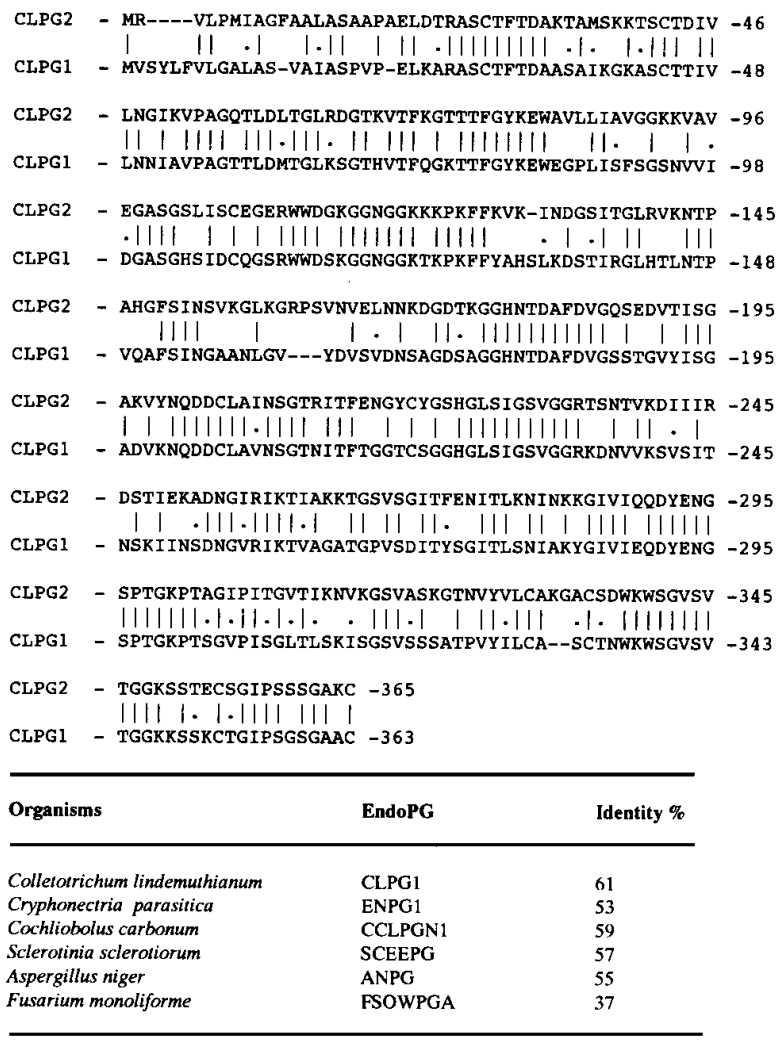

Fig. 2. Comparison between the deduced amino acid sequences of CLPG2 and fungal endopolygalacturonases (endoPGs). Sequence alignment between CLPG2 and CLPG1 deduced amino acid sequences was performed with the PALIGN software program (IntelliGenetics, Geneva, Switzerland). Percentages of identity between the amino acid sequences of CLPG2 and other fungal endoPG are indicated underneath; these were determined for the most favorable alignment in each case by the CLUSTAL software program (IntelliGenetics). Sequence references: Colletotrichum lindemuthianum CLPG1, Centis et al. (1996); Cryphonectria parasitica ENPG1, Gao et al. (1996); Cochliobolus carbonum CCLPGN1, Scott-Craig et al. (1990); Sclerotinia sclerotiorum SCEEPG, Reymond et al. (1994); Aspergillus niger ANPG, Ruttkowski et al. (1990); Fusarium monoliforme FSOWPGA, Caprari et al. (1993).
A

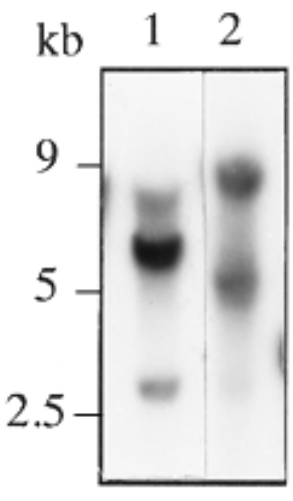

B

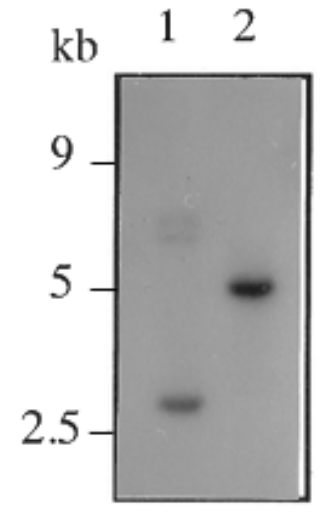

Fig. 3. Southern blot analysis of Colletotrichum lindemuthianum DNA hybridized with $p g A$, a polymerase chain reaction fragment corresponding to a portion of CLPG1 (A) and with the probe specific to CLPG2 (B). Genomic DNA $(5 \mu \mathrm{g})$ of the fungus was digested with $\mathrm{XbaI}$ (lanes 1) and XhoI (lanes 2). Size (kb) of molecular weight markers corresponding to $\lambda$ DNA digested with HindIII is indicated on the left.

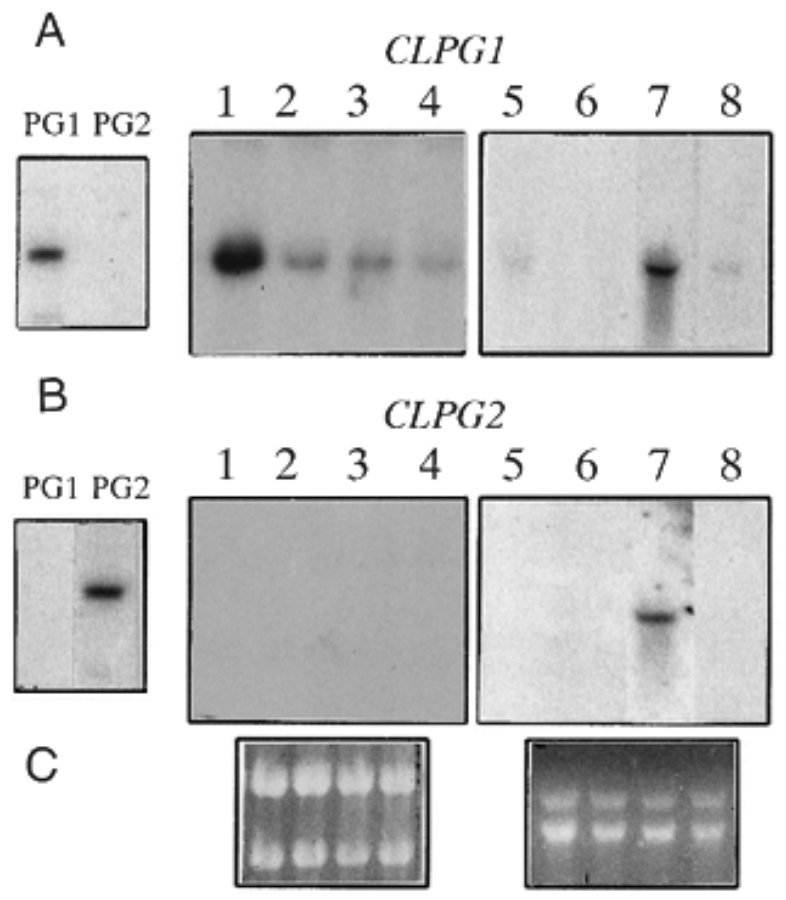

Fig. 4. Expression of $C L P G 1$ and $C L P G 2$ during in vitro culture of the fungus. Specificity of the probes (left panels) was checked by Southern hybridization of the DNA corresponding to the coding sequences of CLPG1 (lanes PG1) or CLPG2 (lanes PG2) to the CLPG1 probe (A) or CLPG2 probe (B). For gene expression studies, total RNA was extracted from a 3-day-old culture (lanes 1 and 3) and from a 5-day-old culture (lanes 2 and 4) of the mycelium. Carbon sources were pectin (lanes 1 and 2) or a mixture of pectin and glucose (lanes 3 and 4). For short timecourse studies, mycelium grown on a glucose medium for 4 days was transferred on a medium containing pectin. Total RNA was extracted at the time of tranfer (lanes 5), and $9 \mathrm{~h}$ (lanes 6), $12 \mathrm{~h}$ (lanes 7), and $18 \mathrm{~h}$ (lanes 8) post transfer. RNA blots were probed to the CLPG1 (A) and CLPG2 (B) specific probes as indicated. Equivalent loading of RNA (10 $\mu \mathrm{g}$ per lane) was assessed by ethidium bromide staining of the gels $(\mathbf{C})$. 
Expression of endoPG genes of $C$. lindemuthianum during bean infection.

Race $\beta$-inoculated, susceptible bean seedlings were used for this study. RNA blot experiments performed on total RNA extracted from infected bean leaves 3 and 5 days postinocula-
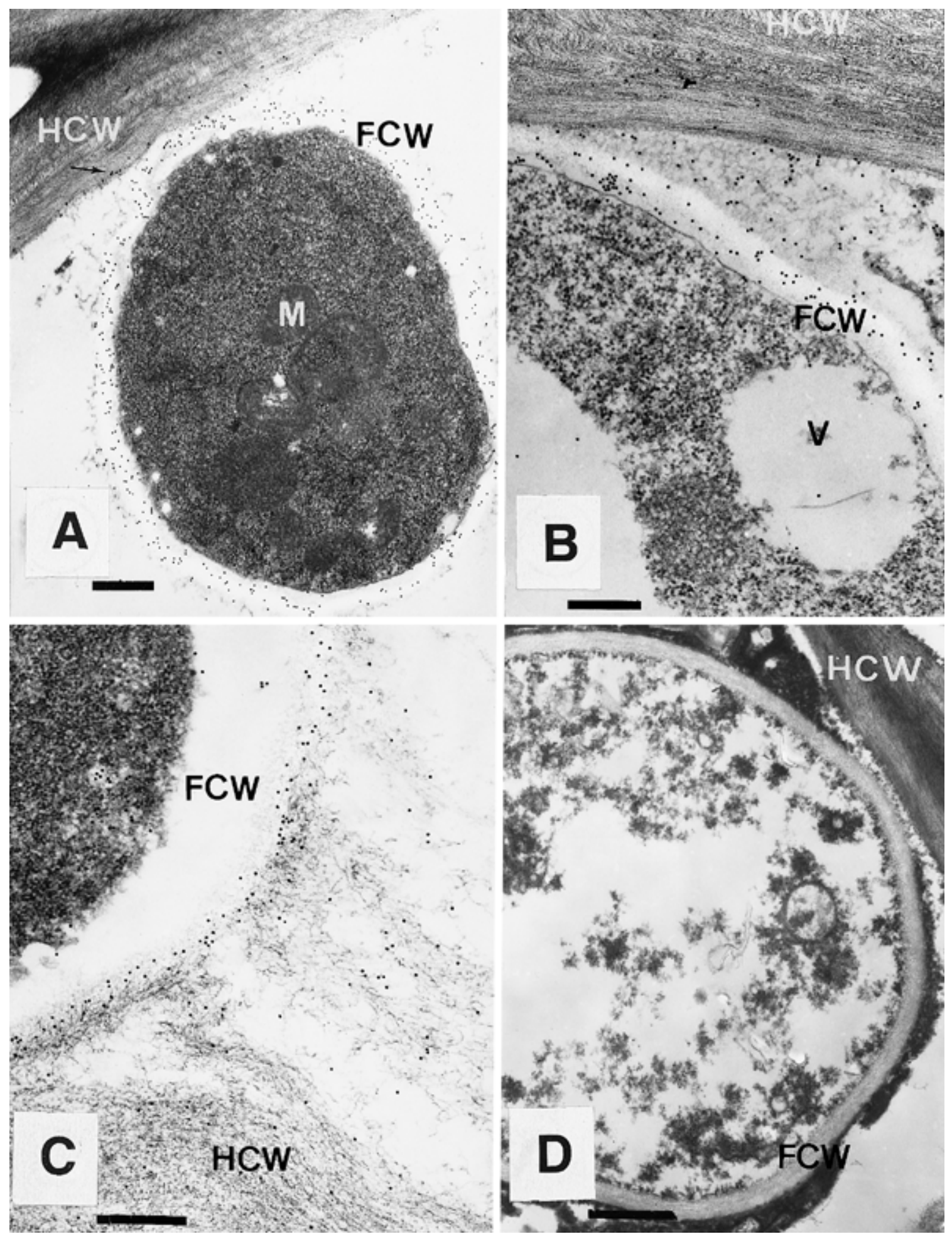

Fig. 5. Immunogold labeling of endopolygalacturonase in Colletotrichum lindemuthianum-infected susceptible bean seedlings. A, Cross section of a fungal hyphae colonizing hypocotyl epidermal cells. Labeling is located in the fungal cell wall $(\times 27,000$; bar $=0.5 \mu \mathrm{m})$. B and $\mathbf{C}$, Higher magnification of an area showing association of the enzyme with the host cell wall $(\times 54,000 ;$ bar $=0.25 \mu \mathrm{m})$. $\mathbf{D}$, Absence of labeling in the control with antiserum preabsorbed with pure endopolygalacturonase $(\times 54,000$; bar $=0.25 \mu \mathrm{m})$. $\mathrm{HCW}=$ host cell wall; $\mathrm{FCW}=$ fungal cell wall; $\mathrm{V}=$ vacuole; $\mathrm{M}=$ mitochondria

tion failed to detect any endoPG gene expression. However, electron microscopy analysis of ultrathin sections performed 3 days postinoculation revealed that epidermal and cortical cells were colonized by the fungus (Fig. 5). At this stage, the necrotrophic phase of the disease had started, as shown by degrada-

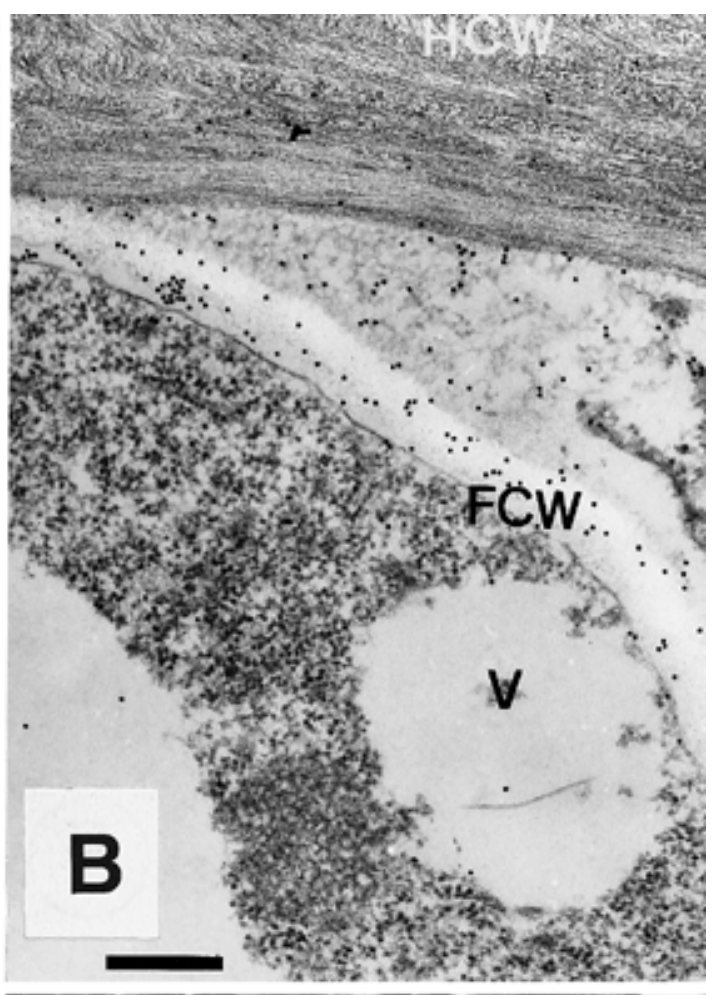


tion of the host cell wall when the mycelium was intercellularly located. Intense immunogold labeling of the fungal cell surface with antibodies against CLPG1 (Hugouvieux et al. 1995), particularly at the interface with the host plant, clearly demonstrated that the protein was abundantly synthesized at this stage (Fig. 5). Thus, the failure to detect endoPG transcripts might result from their dilution in the bulk of total RNA. To overcome this problem, the more sensitive reverse transcription (RT)-PCR technique was employed. To identify the endoPG gene(s) expressed during infection, specific oligoprimers of $C L P G 1$ and $C L P G 2$ located in the coding region of the two genes were synthesized and tested by RT-PCR with total RNA extracted from mycelium grown on pectin medium (data not shown). Total RNA extracted from 3-day- and 5-dayinfected leaves was treated with an RNase-free DNase to avoid amplification of fungal genomic DNA that could contaminate the preparation. RT-PCR was performed on these RNAs and the amplification products were analyzed by Southern hybridization with the probes specific for each endoPG gene. A high hybridization signal of the expected size (1 $\mathrm{kb}$ ) was detected when the RNA extracted from infected plants was amplified with the oligoprimers specific for CLPG1 (Fig. 6). A lower size signal probably reflecting hybridization between one of the primers and an internal sequence of the gene was observed. Oligoprimers specific for $C L P G 2$ did not amplify any transcripts, showing that this gene is not expressed at this time of infection and that the RNA samples were not contaminated by fungal genomic DNA.

\section{DISCUSSION}

The role of cell wall-degrading enzymes as pathogenic determinants in fungi has been re-investigated in recent years through the use of recombinant DNA technology. In a number a cases, notably involving the endoPG of Cochliobolus carbonum and of Cryphonectria parasitica, it has been shown that gene disruption does not alter pathogenicity (Scott-Craig et al. 1990; Gao et al. 1996). This suggests that these enzymes are

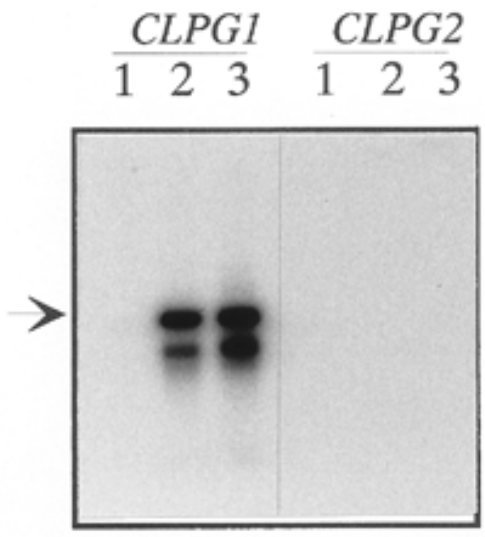

Fig. 6. Analysis by reverse transcription-polymerase chain reaction (RTPCR) of CLPG1 and CLPG2 expression in planta. Total RNA extracted from bean leaves 3 days (lanes 2) and 5 days (lanes 3 ) after inoculation of the susceptible cv. Processor with Colletotrichum lindemuthianum race $\beta$ was used for RT-PCR analysis. PCR products were transferred to a nylon membrane and hybridized to the $C L P G 1$ or $C L P G 2$ probes. Total RNA extracted from ininfected bean plants was also analyzed (lanes 1). Arrow indicates size $(1 \mathrm{~kb})$ of the expected PCR product. not primarily required for colonization of the host. Alternatively, this might result from the fact that hydrolytic enzymes often arise as multiple isoforms whose expression depends on the saprophytic or parasitic stage of the fungus. Thus, Cryphonectria parasitica secretes acidic endoPG isoforms during infection of chestnut stems that were not detected during in vitro culture of the mycelium (Gao et al. 1996). These examples show that a prerequisite to understanding the involvement of such enzymes is the cloning and characterization of the various genes encoding a given function.

The aim of our work on the endoPG of $C$. lindemuthianum is to critically assess the role played by this enzyme during its interaction with the host plant, Phaseolus vulgaris. Toward this end, we previously cloned an endoPG gene called CLPG1 (Centis et al. 1996). In this work, we report on the cloning and characterization of $C L P G 2$, an additional gene with partial homology to CLPG1 and to other endoPG genes from several filamentous fungi.

A major difference resides in CLPG1 and CLPG2 gene expression. When the fungus is grown in vitro, both genes are early and transiently induced by pectin. However, over a longer period of culturing, only CLPGl is expressed on pectin, whereas $C L P G 2$ remains silent. This is consistent with the finding that only one form of endoPG, whose amino acid sequence is identical to that of $C L P G 1$, is present in the medium. Isoelectric focusing of the culture filtrate at times corresponding to CLPG2 gene expression did not allow identification of the corresponding protein product. This suggests that CLPG1 and CLPG2 are indistinguishable on electrophoresis gels due to very similar biochemical properties. The availability of CLPG2 via its production in heterologous host should clarify this point.

Very few studies have been aimed at investigating endoPG gene expression in planta. In the bean-Colletotrichum system, the presence of PGIP precludes measurement of endoPG activity in infected tissues. The sensitive RT-PCR technology allowed us to show that CLPG1 is highly expressed in planta during the necrotrophic phase of parasitism of the fungus. At this stage, CLPG2 is not expressed. However, we cannot exclude a transient expression at earlier stages in a manner similar to that observed in vitro.

This work shows that, although $C$. lindemuthianum contains two endoPG genes, CLPG1 and CLPG2, only CLPG1 is mainly expressed during both the saprophytic and parasitic stages of the fungus. Future work will be aimed at studying the role of each endoPG gene in the Phaseolus-Colletotrichum interaction.

\section{MATERIALS AND METHODS}

\section{Fungal strains.}

Colletotrichum lindemuthianum (Sacc. et Magnus) Lams.Scrib., races $\alpha, \beta$, and $\kappa$ were maintained on synthetic agar (Difco, Detroit, MI) medium as described by Bannerot (1965). Liquid cultures were prepared in 250-ml Erlenmeyer flasks containing $50 \mathrm{ml}$ of synthetic medium, as described by Barthe et al. (1981), supplemented with different carbon sources: $\mathrm{D}(+)$ glucose $\left(10 \mathrm{~g} \cdot \mathrm{l}^{-1}\right)$ or apple pectin $\left(10 \mathrm{~g} \cdot \mathrm{l}^{-1}\right)$ (Sigma, St. Louis, MO). After inoculation of the medium with a suspension of conidia in distilled water to a final concentration of $2 \times$ $10^{3}$ conidia per $\mathrm{ml}$, the cultures were incubated in the dark at 
$23^{\circ} \mathrm{C}$. For short time-course studies, the fungus was first grown on glucose $\left(10 \mathrm{~g} \cdot \mathrm{l}^{-1}\right)$ for 4 days, then the mycelium was washed with sterile water before being transferred to the same pectin-containing medium as above.

\section{Molecular cloning.}

A subgenomic library of $C$. lindemuthianum, race $\beta$ DNA in $\lambda$ ZapII was screened with the CLPG1-derived, 542-bp PCR fragment, previously described (Centis et al. 1996), that was labeled by random priming (Feinberg and Vogelstein 1983). Hybridization was carried out overnight at $65^{\circ} \mathrm{C}$ in $6 \times \mathrm{SSC}$ ( $1 \times \mathrm{SSC}$ is $0.15 \mathrm{M} \mathrm{NaCl}$ plus $0.015 \mathrm{M}$ sodium citrate), $0.5 \%$ sodium dodecyl sulfate (SDS), $5 \times$ Denhardt's solution, $0.1 \%$ denatured calf thymus DNA. The membranes were washed twice with $2 \times \mathrm{SSC}, 0.1 \% \mathrm{SDS}$ at $65^{\circ} \mathrm{C}$ before autoradiography. After two rounds of screening, the selected cloned DNA was recovered by in vivo excision of pBluescript from $\lambda$ ZapII according to the supplier's instructions (Stratagene, La Jolla, $\mathrm{CA}$ ) and sequenced by the dideoxynucleotide method (Sanger et al. 1977).

\section{Southern blot analysis.}

Fungal DNA was isolated by the procedure described by Dellaporta et al. (1983). For Southern blot analysis, $5 \mu \mathrm{g}$ of DNA was loaded per lane. Hybridization conditions were described previously (Centis et al. 1996).

\section{RNA blot analysis.}

Total RNA was isolated from the mycelium of $C$. lindemuthianum according to the method of Haffner et al. (1978). Samples containing $10 \mu \mathrm{g}$ of total RNA were denatured with formamide-formaldehyde and submitted to electrophoresis in a $1.2 \%(\mathrm{wt} / \mathrm{vol})$ agarose gel containing formaldehyde. The gels were transferred to nitrocellulose membranes and fixed by backing for $2 \mathrm{~h}$ at $80^{\circ} \mathrm{C}$ under vacuum. The membranes were then prehybridized for $2 \mathrm{~h}$ at $42^{\circ} \mathrm{C}$ in $50 \%$ formamide, $0.1 \%$ SDS, $1 \times$ Denhardt's solution, $2 \times \mathrm{SSC}$ and $50 \mathrm{ng} \cdot \mathrm{ml}^{-1}$ denatured calf thymus DNA. Hybridization was carried out overnight under the same conditions, after addition of the ${ }^{32} \mathrm{P}$ labeled DNA probe. Digestion of CLPG1 with XhoI and $B a m \mathrm{HI}$, and of $C L P G 2$ with $X b a \mathrm{I}$, allowed preparation of specific probes, i.e., a 780-bp fragment between nucleotides 925 and 1700 of CLPG1 and a 1,950-bp fragment covering CLPG2.

\section{Ultrastructural immunogold labeling.}

Preparation of the samples and labeling were performed according to Benhamou et al. (1991). Hypocotyl segments excised from 7-day-old, susceptible bean seedlings inoculated with $C$. lindemuthianum race $\beta$ were fixed in $3 \%$ glutaralde-

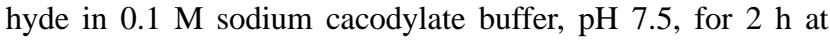
room temperature. Embedding of hypocotyls was carried out in Epon 812 (Euromedex, Strasbourg, France), a hydrophobic resin, after stepwise dehydration in a graded series (from $20 \%$ to $100 \%$ ) of ethanol solutions, completed with a propylene oxide dehydration step. Ultrathin sections were performed with a Reichert microtome OM U3 and collected on collodion-coated gold grids. For immunogold labeling with the antiserum, the ultrathin sections were first pre-incubated for 30 min in a drop of goat anti-rabbit IgG diluted 1/10 in PBS (10 $\mathrm{mM}$ sodium phosphate, $\mathrm{pH} 7.4,150 \mathrm{mM} \mathrm{NaCl}$ ) containing
$0.5 \%$ bovine serum albumin (BSA). They were transferred in the endoPG anti-serum (Hugouvieux et al. 1995) diluted 1/20 in the same buffer and incubated for $2 \mathrm{~h}$ at $37^{\circ} \mathrm{C}$ in a moist chamber. After being rinsed in a PBS-BSA solution, the grids carrying the ultrathin sections were incubated for $1 \mathrm{~h}$ at room temperature in a drop of goat anti-rabbit $\mathrm{IgG}$ conjugated to 15 $\mathrm{nm}$ gold particles, diluted $1 / 20$ in $0.05 \mathrm{M}$ Tris- $\mathrm{HCl}, 0.05 \mathrm{M}$ $\mathrm{NaCl} \mathrm{pH} 8.2,1 \% \mathrm{BSA}$. The grids were thoroughly washed in the Tris-BSA buffer and then in distilled water before being stained with uranyl acetate and lead citrate. The sections were examined in a Philips electron microscope at $80 \mathrm{kV}$.

Specificity of the labeling was assessed by replacing the anti-serum with a non-preimmune serum and by pre-incubation of the anti-serum with the antigen.

\section{PCR procedures.}

RT-PCR was adapted from Frohman et al. (1988). Firststrand cDNAs were synthesized from $1 \mu \mathrm{g}$ of total RNA with 200 units of Moloney murine leukemia virus reverse transcriptase (Promega, Madison, WI), using specific antisense primers of CLPG1 (sense: 5'-CCAAGCTTCAAGATGGTCT CTTACCTCTTCGTGCTCGG-3'; antisense: 5'-GGTCTAG ACTCAGCCGCTTAGCAAGCAGCACCGC-3') and of CLPG2 (sense: 5'-GGATCCAACACCAAGCAAAATGCGC GTCCTC-3'; antisense: 5'-CTCGAGCGAGCGAACCCCTT AGCACTTGC-3') containing extra nucleotides at the $5^{\prime}$ end to add restriction sites to the PCR fragments. The cDNA products were amplified by PCR with specific primers. The PCR parameters (temperature, time, number of cycles) were as follows: $95^{\circ} \mathrm{C}, 1 \mathrm{~min} ; 55^{\circ} \mathrm{C}, 1 \mathrm{~min} ; 72^{\circ} \mathrm{C}, 1 \mathrm{~min} ; 35$ cycles.

\section{ACKNOWLEDGMENTS}

We wish to thank N. Benhamou (Université Laval, Québec, Canada) for help in immunocytolocalization experiments.

\section{LITERATURE CITED}

Albersheim, P., and Anderson, A. J. 1971. Proteins from the plant cell walls inhibit polygalacturonases secreted by plant pathogens. Proc. Natl. Acad. Sci. USA 68:1815-181.

Alghisi, P., and Favaron, F. 1995. Pectin-degrading enzymes and plantparasite interactions. Eur. J. Plant Pathol. 101:365-375.

Bailey, J. A., O'Connell, R. J., Pring, R. J., and Nash, C. 1992. Infection strategies of Colletotrichum species. Pages 88-120 in: Colletotrichum: Biology, Pathology and Control. M. J. Bailey and J. A. Jeger, eds. CAB Int., Wallingford, UK.

Bannerot, H. 1965. Resultats de l'infection d'une collection de haricots par six races physiologiques d'anthracnose. Ann. Amélior. Plantes 15: 201-222.

Barthe, J. P., Cantenys, D., and Touze, A. 1981. Purification and characterisation of two polygalacturonases secreted by Colletotrichum lindemuthianum. Phytopathol. Z. 100:162-171.

Benhamou, N., Lafitte, C., Barthe, J. P., and Esquerré-Tugayé, M.-T. 1991. Cell surface interactions between bean leaf cells and Colletotrichum lindemuthianum. Cytochemical aspects of pectin breakdown and fungal endopolygalacturonase accumulation. Plant Physiol. 97: 234-244.

Caprari, C., Richter, A., Bergmann, C., Lo Cicero, S., Salvi, G., Cervone, F., and De Lorenzo, G. 1993. Cloning and characterization of a gene encoding the endopolygalacturonase of Fusarium moniliforme. Mycol. Res. 97:497-505.

Centis, S., Dumas, B., Fournier, J., Marolda, M., and Esquerré-Tugayé, M.-.T. 1996. Isolation and sequence analysis of CLPG1, a gene coding for an endopolygalacturonase of the phytopathogenic fungus Colletotrichum lindemuthianum. Gene 170:125-129. 
Dellaporta, S. L., Wood, J., and Hicks, J. B. 1983. A plant DNA minipreparation version II. Plant Mol. Biol. Rep. 1:19-21.

Durrands, P. K., and Cooper, R. M. 1988. The role of pectinases in vascular wilt disease as determined by defined mutants of Verticillium albo-altrum. Physiol. Mol. Plant Pathol. 32:363-371.

Feinberg, A. P., and Vogelstein, B. 1983. A technique for labelling DNA restriction endonuclease fragment to high specificity. Anal. Biochem. 132:6-13

Frohman, M. A., Dush, M. K., and Martin, G. R. 1988. Rapid production of full-length cDNAs from rare transcripts: amplification using a single gene-specific oligonucleotide primer. Proc. Natl. Acad. Sci. USA 85:8998-9002.

Gao, S., Choi, G. H., Shain, L., and Nuss, D. L. 1996. Cloning and targeted disruption of enpg-1, encoding the major in vitro extracellular endopolygalacturonase of the chestnut blight fungus, Cryphonectria parasitica. Appl. Environ. Microbiol. 62:1984-1990.

Haffner, M. H., Chin, M. B., and Lane, B. G. 1978. Wheat embryo ribonucleases. XII: formal characterization of terminal and penultimate nucleosides residues at 5 ' end of "capped" RNA from imbibing wheat embryos. Can. J. Biochem. 56:729-733.

Hugouvieux, V., Centis, S., Lafitte, C., and Esquerré-Tugayé, M.-T. 1995. Characterization of Colletotrichum lindemuthianum endopolygalacturonase with molecular probes. C. R. Acad. Sci. Sér. III, Paris 318:113-120

Keon, J. P. R., Waksman, G., and Bailey, J. A. 1990. A comparison of the biochemical and physiological properties of polygalacturonase from two races of Colletotrichum lindemuthianum. Physiol. Mol. Plant Pathol. 37:193-206.

Lafitte, C., Barthe, J.-P., Gansel, X., Dechamp-Guillaume, G., Faucher, C., Mazau, D., and Esquerré-Tugayé, M.-T. 1993. Differential induc- tion by endopolygalacturonase of $\beta-1,3$ glucanases in Phaseolus vulgaris isoline susceptible and resistant to Colletotrichum lindemuthianum race $\beta$. Mol. Plant-Microbe Interact. 6:628-634.

Lafitte, C., Barthe, J.-P., Montillet, J. L., and Touze, A. 1984. Glycoprotein inhibitors of Colletotrichum lindemuthianum endopolygalacturonase in near isogenic lines of Phaseolus vulgaris resistant and susceptible to anthracnose. Physiol. Plant Pathol. 25:39-53.

Reymond, P., Deléage, G., Rascle, C., and Fèvre, M. 1994. Cloning and sequence analysis of a polygalacturonase-encoding gene from the phytopathogenic fungus Sclerotinia sclerotiorum. Gene 146:233-237.

Ruttkowski, E., Labitzke, R., Khanh, N. Q., Loffler, F., Gottschalk, M., and Jany, K. D. 1990. Cloning and DNA sequence analysis of a polygalacturonase cDNA from Aspergillus niger RH5344. Biochim. Biophys. Acta 1087:104-106.

Sanger, F., Nicklen, S., and Coulson, A. R. 1977. DNA sequencing with chain-terminating inhibitors. Proc. Natl. Acad. Sci. USA 74:54635467.

Scott-Craig, J. S., Panaccione, D. G., Cervone, F., and Walton, J. D. 1990. Endopolygalacturonase is not required for pathogenicity of Cochliobolus carbonum on maize. Plant Cell 2:1191-1200.

Walton, J. D. 1994. Deconstructing the cell wall. Plant Physiol. 71:52015205.

Wijesundera, R. L. C., Bailey, J. A., Byrde, R. J. W., and Fielding, A. H. 1989. Cell wall degrading enzymes of Colletotrichum lindemuthianum: Their role in the development of bean anthracnose. Physiol. Mol. Plant Pathol. 34:403-413.

Yao, C., and Köller, W. 1995. Diversity of cutinases from plant pathogenic fungi: Different cutinases are expressed during saprophytic and pathogenic stages of Alternaria brassicicola. Mol. Plant Microbe Interact. 8:122-130. 